\title{
Aortic root surgery in septuagenarians: impact of different surgical
} techniques

\author{
Nawid Khaladj*, Rainer Leyh, Malakh Shrestha, Sven Peterss, Axel Haverich \\ and Christian Hagl
}

\author{
Address: Department of Cardiac, Thoracic, Transplantation and Vascular Surgery, Hannover Medical School, Hannover, Germany \\ Email: Nawid Khaladj* - Khaladj.Nawid@mh-hannover.de; Rainer Leyh - Khaladj.Nawid@mh-hannover.de; \\ Malakh Shrestha - Khaladj.Nawid@mh-hannover.de; Sven Peterss - Khaladj.Nawid@mh-hannover.de; Axel Haverich - Khaladj.Nawid@mh- \\ hannover.de; Christian Hagl - Khaladj.Nawid@mh-hannover.de \\ * Corresponding author
}

Published: 21 April 2009

Journal of Cardiothoracic Surgery 2009, 4:17 doi:10.1186/1749-8090-4-17

Received: 28 January 2009

Accepted: 21 April 2009

This article is available from: http://www.cardiothoracicsurgery.org/content/4/1/17

(C) 2009 Khaladj et al; licensee BioMed Central Ltd.

This is an Open Access article distributed under the terms of the Creative Commons Attribution License (http://creativecommons.org/licenses/by/2.0), which permits unrestricted use, distribution, and reproduction in any medium, provided the original work is properly cited.

\begin{abstract}
Background: To evaluate the impact and safety of different surgical techniques for aortic root replacement (ARR) on early and late morbidity and mortality in septuagenarians undergoing ARR.

Methods: Ninety-five patients $(73.8 \pm 3.2$ years $)$ were operated and divided into three groups according to the aortic root procedure; $\mathrm{MECH}$-group $(n=5 \mathrm{I})$ patients with a mechanical composite graft, BIO-group $(\mathrm{n}=22)$ patients with a customized biological composite graft, and REIMPL-group $(n=22)$ patients with a valve sparing aortic root reimplantation (David I). In $42.1 \%$ (40/95) of these patients the aortic arch was replaced. Follow-up was completed in $95.2 \%(79 / 83)$ of in-hospital survivors.
\end{abstract}

Results: Hospital mortality was $12.6 \%$ (I2/95) in the entire population (MECH. 15.7\% (8/5I), BIO 19.7\% (4/22), REIMPL 0\% (0/22); $\mathrm{p}=0.004)$. Two patients died intraoperatively. The most frequent postoperative complications were prolonged mechanical ventilation $((>48 \mathrm{~h})$ in $16.8 \%(16 / 93)$ (MECH. 7\% (7/5I), BIO 36.4\% (8/22), REIMPL 4.5\% (I/22); $p=0.013)$ and rethoracotomy for postoperative bleeding in $12.6 \%$ (I2/95) (MECH. I2\% (6/5), BIO 22.7\% (5/22), REIMPL 4.5\% (I/ $22) ; \mathrm{p}=0.19)$. Nineteen late deaths $(22.9 \%)(19 / 83)(\mathrm{MECH} 34.8 \%(15 / 43), \mathrm{BIO} 16.7 \%(3 / 18)$, REIMPL $4.5 \%(\mathrm{I} / 22) ; \mathrm{p}=0.012$ ) occurred during a mean follow-up of $4 \mathrm{I} \pm 42$ months (MECH 48 \pm 48 months, BIO $25 \pm 37$ months, REIMPL $40 \pm 28$ months, $p=0.028$ ). Postoperative NYHA class decreased significantly $(p=0.017)$ and performance status $(p=0.027)$ increased for the entire group compared to preoperative values.

Conclusion: Our data indicate that valve sparing aortic root reimplantation is safe and effective in septuagenarians, and is associated with low early and late morbidity and mortality.

\section{Background}

Aortic root replacement has become a generally accepted treatment modality for a variety of aortic root pathologies. Basically, two different surgical procedures and their mod- ifications have been advocated. Composite graft valve replacement (CVR) of the aortic root applying different techniques for reimplantation of the coronary ostia, and different types of valve sparing aortic root replacement 
techniques [1-5]. Although results of these techniques have been extensively described only limited data from the literature are available about these surgical techniques in older patients [6-13]. Furthermore, different techniques for aortic root replacement in septuagenarians have not been evaluated yet. Thus, the aim of this study was to evaluate the impact and safety of different surgical techniques for aortic root replacement (ARR) on early and late morbidity and mortality as well as functional status in septuagenarians undergoing aortic root replacement.

\section{Patients and methods}

This study was approved by the institutional review board; all patients gave written informed consent.

Between 1988 and 2003, 95 patients 70 years of age or older underwent aortic root replacement at our institution. Preoperative patient's characteristics are depicted in Table 1. According to the aortic root procedure the patients were divided into three groups. MECH-group ( $\mathrm{n}$ $=51$ ) patients who received a mechanical composite valve graft, BIO-group $(\mathrm{n}=22)$ patients who received a custom- ized biological composite valve graft, and REIMPL-group $(\mathrm{n}=22)$ patients who received a valve sparing aortic root reimplantation (David I). Concerning the surgical procedure, the choice between a mechanical and biological valve graft conduit were on the patient's decision. In patients with pure aortic insufficiency and macroscopically normal aortic leaflets the decision to perform valve sparing aortic root reimplantation was dictated by the surgeon's preference.

We obtained clinical data by retrospective review of the hospital archives and follow-up information was gathered from direct telephone interview of the patient or a close relative, and contact with the referring physician. Infectious, thrombembolic and bleeding complications were recorded as required by the guidelines of the American Association for Thoracic Surgery/Society of Thoracic Surgeons [14]. Furthermore current NYHA-Status and performance status scale (Karnofsky) were requested [15].

Thromboembolism, hemorrhage requiring hospitalisation, aortic valve re-operations or endocarditis were con-

Table I: Preoperative patient's characteristics and hemodynamics

\begin{tabular}{|c|c|c|c|c|c|}
\hline Variable & $\begin{array}{l}\text { I. MECH-group } \\
n=51\end{array}$ & $\begin{array}{l}\text { 2. BIO-group } \\
n=22\end{array}$ & $\begin{array}{l}\text { 3. REIMPL-group } \\
\mathrm{n}=22\end{array}$ & $\begin{array}{l}\text { All } \\
\mathrm{n}=95\end{array}$ & $p$-value \\
\hline \multicolumn{6}{|l|}{ Age at surgery (years) } \\
\hline mean $\pm S D$ & $73.1 \pm 2.7$ & $75.2 \pm 3.8$ & $74.1 \pm 3.7$ & $73.8 \pm 3.2$ & 0.031 \\
\hline range & $70-80$ & $70-82$ & $70-83$ & $70-83$ & \\
\hline Male, n (\%) & $29(56.9)$ & $9(40.9)$ & $10(45.5)$ & $48(5 \mathrm{I})$ & n.s. \\
\hline $\operatorname{BSA}\left(m^{2}\right)$ & $1.83 \pm 0.21$ & $1.78 \pm 0.19$ & $1.84 \pm 0.24$ & $1.82 \pm 0.21$ & n.s. \\
\hline NYHA (mean \pm SD) & $3.06 \pm 0.81$ & $3.0 \pm 0.58$ & $2.62 \pm 0.74$ & $2.94 \pm 0.75$ & 0.007 \\
\hline NYHA $\geq \mathrm{III}, \mathrm{n}(\%)$ & $40(78.4)$ & $19(86.4)$ & $15(68.2)$ & $69(72.6)$ & 0.031 \\
\hline Redo, n (\%) & $16(31.4)$ & I (4.5) & 0 & $17(17.9)$ & 0.001 \\
\hline Endocarditis, n (\%) & $4(7.8)$ & $\mathrm{I}(4.5)$ & 0 & $6(6.3)$ & n.s. \\
\hline$\varnothing$ ascending aorta $(\mathrm{mm})$ & $63 \pm 13$ & $62 \pm 10$ & $65 \pm 13$ & & \\
\hline \multicolumn{6}{|l|}{ Comorbitities, n (\%) } \\
\hline $\mathrm{AF}$ & $12(23.5)$ & $7(31.8)$ & $2(9.1)$ & $21(22.1)$ & n.s. \\
\hline MI & $4(7.8)$ & $3(18.1)$ & 0 & $7(7.3)$ & n.s. \\
\hline Ventricular arrhythmias & $2(3.9)$ & 0 & 0 & $2(2.1)$ & n.s. \\
\hline Heart failure history & $24(47.1)$ & $8(36.4)$ & $4(18.2)$ & $36(37.9)$ & n.s. \\
\hline Systemic hypertension & $26(5 \mathrm{I})$ & $16(72.7)$ & $18(8 \mid .2)$ & $60(63.2)$ & 0.026 \\
\hline Diabetes & $5(9.8)$ & $3(13.6)$ & $3(13.6)$ & II (II.6) & n.s. \\
\hline Hyperlipidemia & $9(17.6)$ & $9(40.9)$ & $7(31.8)$ & $25(26.3)$ & n.s. \\
\hline Creatinine $\geq 120 \mu \mathrm{mol} / \mathrm{L}$ & $9(17.6)$ & $7(31.8)$ & $2(9.1)$ & $17(17.9)$ & n.s. \\
\hline COPD & $9(17.6)$ & $5(22.7)$ & $2(9.1)$ & $16(16.8)$ & n.s. \\
\hline Stroke & I (I.9) & $3(13.6)$ & $2(9.1)$ & $6(6.3)$ & n.s. \\
\hline TIA/PRIND & $2(3.9)$ & I (4.5) & 0 & $4(3.1)$ & n.s. \\
\hline \multicolumn{6}{|l|}{ Hemodynamics } \\
\hline LVEF (\%) & $56.8 \pm 11.5$ & $58.6 \pm 13.3$ & $60.7 \pm 13.8$ & $58.3 \pm 12.5$ & n.s. \\
\hline $\operatorname{LVEDP}(\mathrm{mmHG})$ & $17.2 \pm 9.4$ & $15.1 \pm 6.2$ & $15.7 \pm 6.9$ & $16.4 \pm 8.2$ & n.s. \\
\hline mean PAP (mmHG) & $25.6 \pm 9.6$ & $26.8 \pm 11$ & $21 \pm 6$ & $24.8 \pm 9.4$ & n.s. \\
\hline $\mathrm{Cl}\left(\mathrm{L} \times \mathrm{min}^{-1} \times \mathrm{m}^{-2}\right)$ & $2.7 \pm 1.5$ & $2.4 \pm 0.5$ & $2.7 \pm 0.9$ & $2.6 \pm 0.9$ & n.s. \\
\hline mean RAP (mmHG) & $5.9 \pm 3.8$ & $7.8 \pm 3.3$ & $6.9 \pm 3.1$ & $6.7 \pm 3.5$ & n.s. \\
\hline
\end{tabular}

BSA, body surface area; NYHA, New York Heart Association; AF, Atrial fibrillation; MI, previous myocardial infarction; COPD, chronic obstructive pulmonary disease; TIA, transient ischemic attack; PRIND, prolonged reversible ischemic neurological deficit; LVEF, left ventricular ejection fraction; LVEDP, left ventricular endiastolic pressure, $\mathrm{PAP}$, pulmonary artery pressure; $\mathrm{Cl}$, cardiac index; RAP, right atrial pressure. 
sidered to be valve related. Follow-up was complete for $95.2 \%$ (79/83) of hospital survivors.

\section{Surgical technique}

Standard cardiopulmonary bypass with a membrane oxygenator and systemic moderate hypothemia $\left(28^{\circ} \mathrm{C}\right.$ to $32^{\circ} \mathrm{C}$ ) was used unless otherwise indicated. In cases with aortic arch aneurysms either moderate hypothermic circulatory arrest with cold $\left(15^{\circ} \mathrm{C}\right)$ antegrade cerebral perfusion or deep hypothermia $\left(16^{\circ} \mathrm{C}\right.$ to $\left.20^{\circ} \mathrm{C}\right)$ with circulatory arrest was utilized [16]. Antegrade cold potassium crystalloid or blood cardioplegic solution was used for myocardial protection. The left ventricle was vented through a transmitral catheter. The decision whether to perform valve sparing aortic root reimplantation or composite replacement of the aortic root was made intraoperatively in patients with pure aortic regurgitation, and depended on the quality of the aortic valve leaflets as well as on the surgeon's decision. In patients with aortic stenosis or mixed aortic valve pathology either a mechanical or a biological composite valve graft was implanted. All patients included in this study receiving a mechanical or biological composite valve graft (CVG) had a button Bentall operation [4]. Biological conduits were manufactured by selecting appropriate size valve prosthesis and suturing a vascular graft to it, yielding a readily usable unit as described by Galla and co-workers [17]. Patients selected for valve sparing aortic root replacement were operated upon the classic David I technique as described previously [18].

The associated operative procedures as well as operative data are summarized in Table 2.

\section{Statistical methods}

Continuous variables are expressed as mean \pm SD. Categoric data are given as total numbers and relative frequencies; continuous data are given as mean $\pm \mathrm{SD}$, except where otherwise stated. Groups were compared by one way ANOVA. Stepwise logistic regression was used for multivariate analysis. The Kaplan-Meier survival estimates were used to analyze long-term survival, and freedom from valve related complications. Statistical differences in Kaplan-Meier survival estimates were determined by using the log-rank test. All data analyses were performed with SPSS 15.0 for Windows (SPSS, Chicago, IL, USA).

\section{Results}

As a result of the surgical policy, there was a consistently increasing caseload of patient receiving either a biological composite graft or a valve sparing aortic root reimplantation over the study period (1988-1992: MECH 12 pts., 1993-1998: MECH 13 pts., BIO 3 pts., REIMPL 2 pts., 1998-2003: MECH 26 pts., BIO 19 pts., REIMPL 20 pts.).

Patient's preoperative data are depicted in Table 1. The patient groups were comparable beside the age, incidence of previous cardiac surgery and arterial hypertension as well as NYHA-status. Preoperative hemodynamics did not show any significant differences between groups. Five patients that were operated on an emergency basis received a mechanical conduit.

Intraoperative variables are shown in Table 2. The REIMPL-group had a significantly longer aortic cross clamp time compared to the $\mathrm{MECH}$-group and BIOgroup. The most frequent concomitant surgical procedure was aortic arch replacement (42.1\%) and coronary artery bypass grafting (CABG) (29.5\%). However, the BIOgroup had a significantly higher number of aortic arch replacement performed compared to the MECH-group, furthermore, the percentage of selective antegrade cerebral perfusion (SACP) for cerebral protection was significantly higher in this BIO-group compared to the other patient groups. SACP is routinely performed in our institution since 1999.

Table 2: Intraoperative data

\begin{tabular}{|c|c|c|c|c|c|}
\hline Variable & $\begin{array}{l}\text { I. MECH-group } \\
\mathrm{n}=5 \mathrm{I}\end{array}$ & $\begin{array}{l}\text { 2. BIO-group } \\
n=22\end{array}$ & $\begin{array}{l}\text { 3. REIMPL-group } \\
\mathrm{n}=22\end{array}$ & $\begin{array}{l}\text { All } \\
\mathrm{n}=95\end{array}$ & $p$-value \\
\hline CPB time (min.) & $144 \pm 60$ & $178 \pm 140$ & $159 \pm 27$ & $156 \pm 82$ & n.s. \\
\hline ACC time (min.) & $91 \pm 31$ & $107 \pm 39$ & $123 \pm 18$ & $103 \pm 33$ & $<0.001$ \\
\hline AA-replacement, n (\%) & $16(31.4)$ & $15(68.2)$ & $9(40.9)$ & $40(42.1)$ & 0.014 \\
\hline hemiarch, n (\%) & $15(93.8)$ & $15(100)$ & $7(77.8)$ & 37 & 0.018 \\
\hline total arch, $\mathrm{n}(\%)$ & $\mathrm{I}(6.2)$ & 0 & $2(22.2)$ & 3 & n.s. \\
\hline CA time (min.) & $15.5 \pm 5.7$ & $17.1 \pm 8$ & $17.7 \pm 7.7$ & $16.6 \pm 7$ & n.s. \\
\hline SACP, n (\%) & $7(44.4)$ & $15(100)$ & $6(66.7)$ & $28(70)$ & $<0.001$ \\
\hline MVS & $4(7.8)$ & $3(13.6)$ & 0 & 7 & n.s. \\
\hline CABG, n (\%) & II (2I.6) & $9(40.9)$ & $7(31.8)$ & $28(29.5)$ & n.s. \\
\hline Intraoperative death, $\mathrm{n}(\%)$ & $2(3.9)$ & 0 & 0 & $2(2.1)$ & n.s. \\
\hline
\end{tabular}

CPB, cardio pulmonary bypass; ACC, aortic cross clamp; AA-replacement, aortic arch replacemen; SACP, selective antegrade cerebral perfusion, CA, circulatory arrest; MVS, mitral valve surgery, CABG, coronary artery bypass grafting. 


\section{Hospital morbidity and mortality}

Early postoperative complications are shown in Table 3. The most frequent complications were postoperative pulmonary insufficiency requiring prolonged ventilation of patients and rethoracotomy for bleeding complications, with no statistical differences between groups. Postoperative pulmonary insufficiency occurred more often in the BIO-group (36.4\%) ( $\mathrm{p}=0.013) .10$ patients died within 30 days, in addition to the two intraoperative death the overall hospital mortality was $12.6 \%$ with a statistical significant difference between groups $(\mathrm{p}=0.004)$. The causes of death are summarized in Table 4. Stepwise logistic regression revealed a history of preoperative cardiac decompensation ( $\mathrm{p}=0.026$, OR $3.9(1.1-14.295 \% \mathrm{CI})$ ), rethoracotomy ( $\mathrm{p}=0.001$, OR $12.8(3.1-52.2$ 95\% CI) and postoperative pneumonia ( $\mathrm{p}=0.002$, OR 8.1 (1-64 $95 \% \mathrm{CI})$ ) as independent predictors for in hospital mortality.

\section{Follow-up morbidity and mortality}

The follow-up was $41 \pm 42.3$ months (1-173 months) for the entire cohort. The follow-up time showed a significant difference between groups (MECH-group $49 \pm 48$ months, BIO-group $25 \pm 36.9$ months, and REIMPLgroup $40 \pm 28$ months, $\mathrm{p}=0.028$ ). Follow-up revealed 22 late deaths, 6 patients died of cardiac related reason, 3 of valve related reasons. Thus mean survival for the entire patient population was $8 \pm 1$ years and showed significant difference between groups as depicted in Figure 1 and Figure 2.
23 hospital survivors had to be readmitted to the hospital, 7 for valve related complications, 2 for cardiac related complications and 14 for other reasons. During follow-up 3 patients had to be re-operated on, all patients had prosthetic valve endocarditis, two of these patients died (freedom from re-operation $96.2 \%$ ).

Postoperative NYHA-Status decreased significantly for the entire cohort as well as patients in the MECH-group and BIO-group (Figure 3). The performance status of the entire group $(78 \pm 7.5 \%$ to $81.1 \pm 13.2 \%, \mathrm{p}=0.017)$ as well for the MECH-group $(76.5 \pm 7.8 \%$ to $82.6 \pm 12.5 \%$, $\mathrm{p}=$ $0.015)$ and BIO-group $(76.4 \pm 8.1 \%$ to $81.3 \pm 14.1 \%, \mathrm{p}=$ $0.027)$ slightly increased.

\section{Discussion}

In this study we demonstrated that different complex surgical techniques for ARR can be performed with good results in septuagenarians. Our data indicate that valve sparing aortic root reimplantation is an excellent alternative to composite conduits with bioprostheses or mechanical prostheses for septuagenarians with favourable short and long-term outcome.

Composite valve replacement has become a generally accepted surgical technique for the treatment of aortic root pathology with acceptable perioperative mortality rates and good long-term results $[6,8,9,11,12,18-21]$. The mortality rate for ARR with composite valve grafts in recent publications varies between $0.7 \%$ and $11 \%$ with a survival rate from $76 \%$ to $91.8 \%$ at 5 years and $62 \%$ to $76 \%$ at 10 years. Furthermore, Urbanski and associates

Table 3: Postoperative data of patients surviving the operation

\begin{tabular}{|c|c|c|c|c|c|}
\hline Variable & $\begin{array}{l}\text { MECH-group } \\
n=49\end{array}$ & $\begin{array}{l}\text { BIO-group } \\
n=22\end{array}$ & $\begin{array}{l}\text { REIMPL-group } \\
\mathrm{n}=22\end{array}$ & $\begin{array}{l}\text { All } \\
n=95\end{array}$ & $p$-value \\
\hline \multicolumn{6}{|l|}{ ICU stay (days) } \\
\hline mean $\pm S D$ & $3.8 \pm 6.2$ & $3.7 \pm 4$ & $3.2 \pm 4.7$ & $3.6 \pm 5.3$ & n.s. \\
\hline range & $1-37$ & $1-15$ & $1-23$ & $1-37$ & \\
\hline \multicolumn{6}{|l|}{ artificial ventilation (hours) } \\
\hline mean $\pm S D$ & $112 \pm 187$ & $64 \pm 93$ & $45 \pm 87.8$ & $79 \pm 137$ & n.s. \\
\hline range & $24-792$ & $12-360$ & $11-160$ & $11-192$ & \\
\hline blood loss (ml) & $1|28 \pm 9| 4$ & $926 \pm 882$ & $833 \pm 650$ & $999 \pm 839$ & n.s. \\
\hline red blood cells (units) & $2.5 \pm 2.8$ & $3.9 \pm 3.5$ & $2.9 \pm 2$ & $3.2 \pm 3$ & n.s. \\
\hline fresh frozen plasma (units) & $3 \pm 2.1$ & $3.4 \pm 1.9$ & $2.7 \pm 1.86$ & $3.1 \pm 1.9$ & n.s. \\
\hline rethoracotomy, n (\%) & $6(11.8)$ & $5(22.7)$ & I (4.5) & $12(12.9)$ & n.s. \\
\hline LCO, n (\%) & $2(3.9)$ & I (4.5) & 0 & 5 & n.s. \\
\hline MOF, n (\%) & $3(5.9)$ & $3(13.6)$ & 0 & 6 & n.s. \\
\hline MI, n (\%) & 0 & I (4.5) & 0 & 1 & n.s. \\
\hline Stroke, n (\%) & I (2) & I (4.5) & 0 & 3 & n.s. \\
\hline Pneumonia, n (\%) & $4(7.8)$ & 0 & 0 & 3 & n.s. \\
\hline Sepsis, n (\%) & $4(7.8)$ & I (4.5) & 0 & 5 & n.s \\
\hline Pulmonary insufficiency, n (\%) & $7(13.7)$ & $8(36.4)$ & I (4.5) & 16 & 0.013 \\
\hline Hospital mortality, n (\%) & $9(17.6)$ & $3(13.5)$ & 0 & $12(12.6)$ & 0.004 \\
\hline
\end{tabular}

ICU, intensiv care unit; LCO, low cardiac output; MOF, multiorgan failure; MI, myocardial infarction. 
Table 4: Causes of hospital mortality according to the surgical technique

\begin{tabular}{|c|c|c|c|c|}
\hline Cause of hospital mortality & $\begin{array}{l}\text { MECH-group } \\
n=5 I\end{array}$ & $\begin{array}{l}\text { BIO-group } \\
n=22\end{array}$ & $\begin{array}{l}\text { REIMPL-group } \\
\mathrm{n}=22\end{array}$ & $\begin{array}{l}\text { All } \\
\mathrm{n}=95\end{array}$ \\
\hline Heart failure (intraoperative), n (\%) & $2(3.9)$ & & & $2(2.1)$ \\
\hline Heart failure (postoperative), n (\%) & $4(7.8)$ & I (4.5) & & $5(5.3)$ \\
\hline Myocardial infarction, $\mathrm{n}(\%)$ & & I (4.5) & & $\mathrm{I}(1.0)$ \\
\hline Sepsis, n (\%) & $2(3.9)$ & & & $2(2.1)$ \\
\hline Stroke, n (\%) & I (2) & $\mathrm{I}(4.5)$ & & $2(2.1)$ \\
\hline$\Sigma$ hospital mortality, $\mathrm{n}(\%)$ & $9(17.6)$ & $3(13.5)$ & 0 & $12(12.6)$ \\
\hline
\end{tabular}

showed in a case matched study with 200 patients, that ARR can be performed with a similar operative risk, valve related morbidity and late mortality as isolated aortic valve replacement [21]. However, recent published series showed that valve sparing aortic root replacement techniques are a valuable option for patients with macroscopically normal leaflets $[3,10]$. The hospital mortalities in these studies vary around $3-5 \%$. The functional results showed freedom from re-operation in $94-99 \%$ of different sub cohorts.

In the vast majority of these studies the patients were younger. Due to the limited data from the literature there is still an ongoing debate whether ARR should be performed in elderly patients $>70$ years due to an anticipated higher mortality rate for ARR compared to isolated aortic

\section{Survival function}

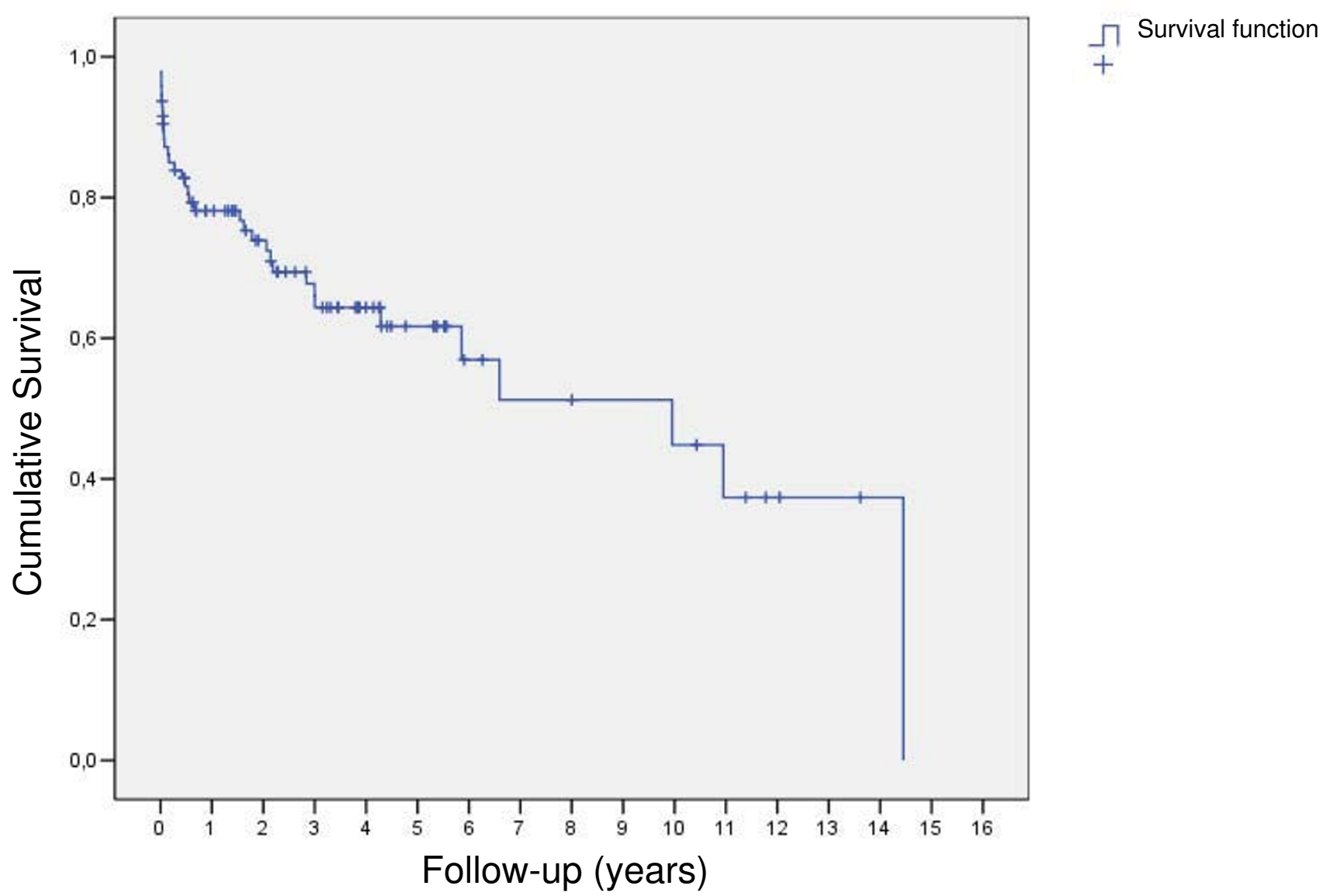

Figure I

Survival curve for the entire study population. 


\section{Survival function}

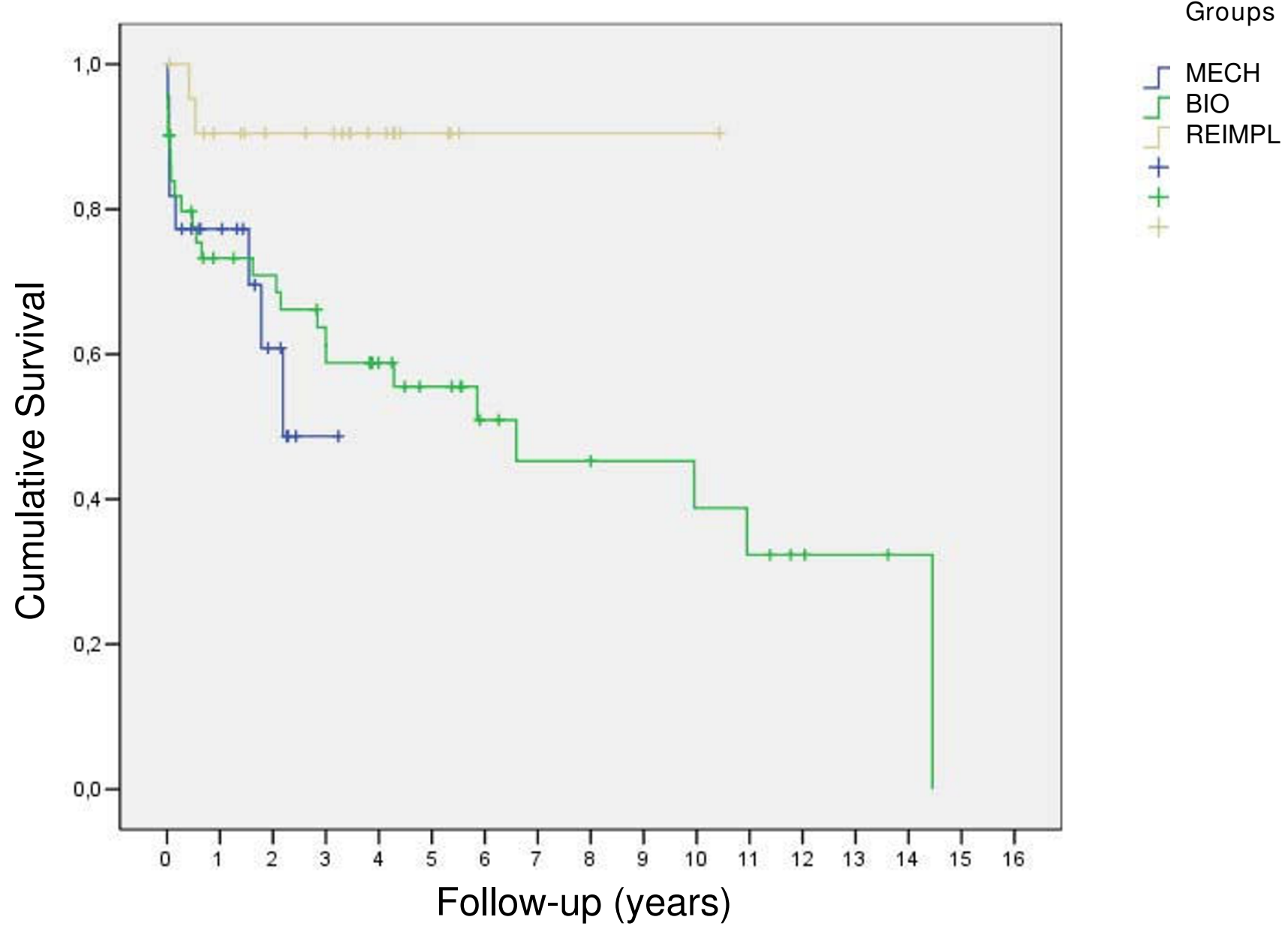

Figure 2

Survival curves for the sub groups.

valve replacement. Only sparse data are available from the literature dealing with the problem of ARR in septuagenarians [8]. Ehrlich and co-workers described a hospital mortality of $8.3 \%$ ( 7 of 84 ). This is comparable to the $5 \%-11.4 \%$ hospital mortality after aortic valve replacement in the same age group [22-24].

In our study, two patients died intra-operatively, and another 10 within the first 30 day or during hospital stay (12/95 pts., $12.6 \%)$. Our institutional mortality for this age group ranges from $8 \%$ for cardiac surgery up to $29 \%$ in patients undergoing surgery for acute type A aortic dissection $[25,26]$. In other studies we revealed age and comorbidities as predictors for morbidity and mortality $[27,28]$. We strongly believe that the mortality rate is influenced by the amount of co-morbidities rather than the surgical technique.

The standard approach to ARR is the use of composite grafts with a mechanical prosthesis [29]. Composite conduits with stented bioprosthesis have shown reasonable results $[9,17]$. Etz and associates recently published their experience with 206 patients receiving custom made composite conduits with a stented bioprosthesis (mean age 53 years) with a hospital mortality rate of $2.9 \%$ and a 10 year survival rate of $89 \%$ [9]. Only a limited number of reports compared mechanical and biological ARR [6,8]. Ehrlich and co-workers showed that overall probability of survival was similar for patients with composite grafts incorporating a mechanical or biological valve (mean age 73.9 years; 


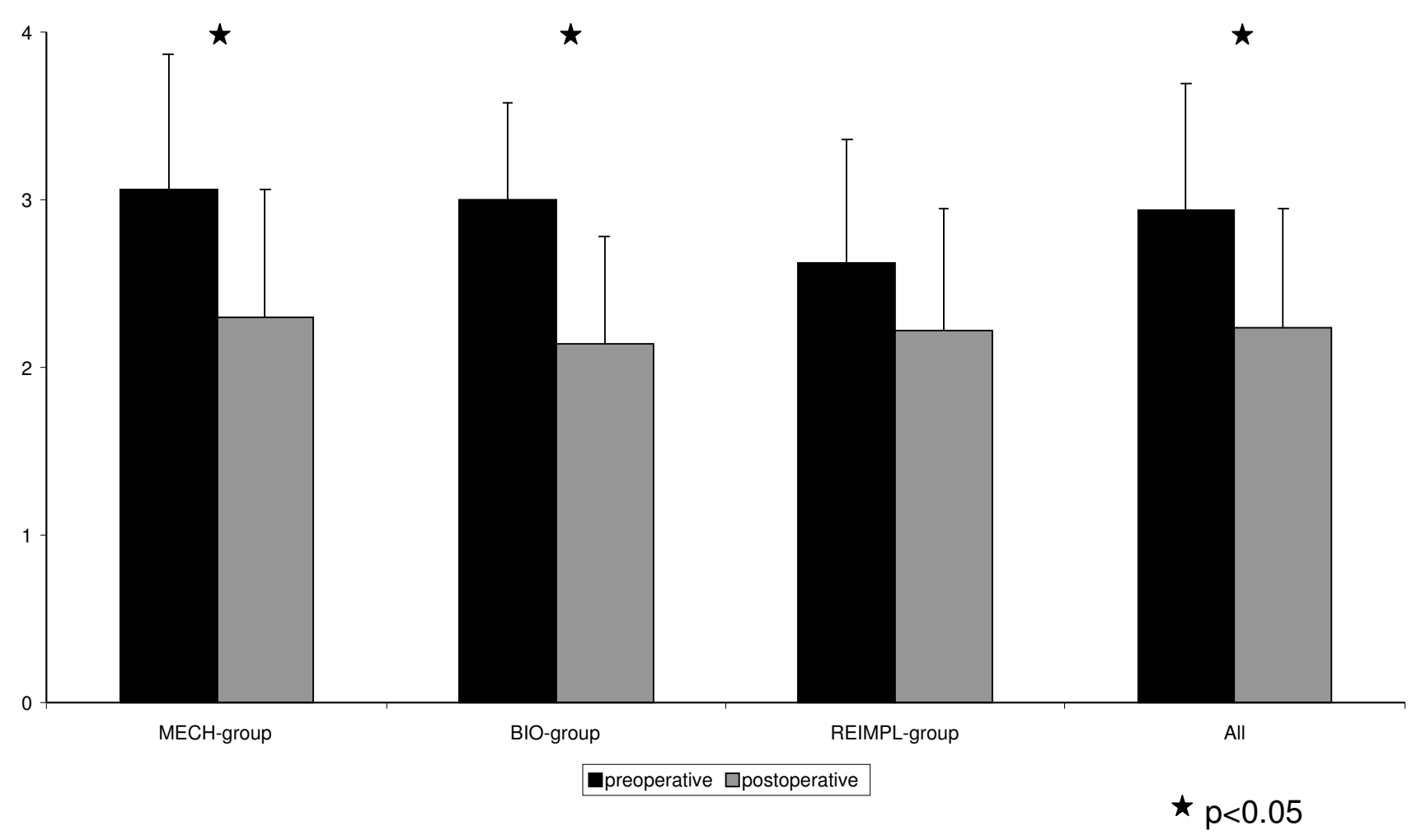

Figure 3

NYHA-Status of the patients pre- and postoperatively.

$\mathrm{n}=84$ ) with a 5 year survival of approximately $60 \%$ in both groups. Interestingly in this study survival was similar to that of an age-matched population. Byrne et al. compared biological and mechanical root replacement in a younger patient cohort with a median age of 53 years respectively 54 years and could neither demonstrate a difference in hospital mortality (1.5\% vs. $2.4 \%)$ nor in the 5 year survival rate ( $92.4 \%$ vs. $88.2 \%$ ). However, in the biological root replacement group either aortic homografts or stentless aortic valves were implanted.

In the present study, mean survival was $7 \pm 1$ years for the entire cohort, with best results for patients in the REIMPLgroup (5-year survival rate $80 \%$ ). The impact of pure aortic insuffiency on results in this subgroup in controversially discussed. A substantial number of patients receiving a mechanical or biological composite graft had either mixed AS/AI or AS only; in contrast patients scheduled for aortic root reimplantation had pure AI only. The impact of different physiological subgroups (aortic regurgitation vs. aortic stenosis vs. stenosis/regurgitation) on early and late outcome after aortic valve surgery is still dis- cussed controversially. Scott and associates analysed 1,479 isolated aortic valve replacement procedures and showed substantial differences in operative mortality rates among physiological subgroups [30]. In contrast Nowicki and colleagues reported on 5793 patients undergoing aortic valve surgery and found no impact of valve diagnosis on in-hospital mortality [31]. However, in both studies no long-term results have been analysed.

For surgeons not familiar with valve sparing aortic root procedures ARR with composite conduits is still a valuable option. Whereas in this patient composite graft replacement with stented bioprosthesis is omitting lifelong oral anticoagulation und consequent avoidance of bleeding complications [32].

\section{Limitations}

Patient's demographic and intraoperative data differed significantly between groups in terms of number of previous cardiac operations, preoperative NYHA functional class, and incidence of aortic arch replacement, all factors that may reflect a selection bias for a certain operative 
technique. However, the multivariate analysis revealed none of these factors as a predictor for hospital mortality. Since this is a nonrandomised retrospective study covering the experience of 15 years, factors influencing the outcome may have been missed and not analysed thus could falsify the result of the multivariate analysis. However, current factors that already proofed to have a potential influence as predictors for hospital mortality and longterm mortality have been proven.

\section{Conclusion}

The small number of patients in each group makes it difficult to draw definite conclusion about the impact of different surgical techniques for ARR on early and late outcome.

However, our data indicate that valve sparing aortic root Reimplantation is safe and effective in septuagenarians, and is associated with low early and late morbidity and mortality.

\section{Competing interests}

The authors declare that they have no competing interests.

\section{Authors' contributions}

NK and RL designed the study and wrote the manuscript, MS and SP were responsible for data acquisition, interpretation and statistical analysis, $\mathrm{AH}$ and $\mathrm{CH}$ revised the manuscript for important intellectual content and have given the final approval of the version to be published.

\section{Acknowledgements}

This work was supported by the German Research Foundation (HA 297I/ 2-2).

\section{References}

I. Bentall $\mathrm{H}$, De Bono A: A technique for complete replacement of the ascending aorta. Thorax 1968, 23:338-339.

2. Cabrol C, Pavie A, Gandjbakhch I, Villemot JP, Guiraudon G, Laughlin $L$, Etievent $P$, Cham B: Complete replacement of the ascending aorta with reimplantation of the coronary arteries: new surgical approach. I Thorac Cardiovasc Surg 198I, 81:309-3I5.

3. David TE, Ivanov J, Armstrong S, Feindel CM, Webb GD: Aortic valve-sparing operations in patients with aneurysms of the aortic root or ascending aorta. Ann Thorac Surg 2002, 74:SI758-I76I. discussion SI792-I759.

4. Kouchoukos NT: Composite aortic valve replacement and graft replacement of the ascending aorta plus coronary ostial reimplantation: how I do it. Semin Thorac Cardiovasc Surg 1993, 5:66-70.

5. Yacoub MH, Gehle P, Chandrasekaran V, Birks EJ, Child A, RadleySmith $R$ : Late results of a valve-preserving operation in patients with aneurysms of the ascending aorta and root. J Thorac Cardiovasc Surg 1998, II 5:1080-1090.

6. Byrne JG, Gudbjartsson T, Karavas AN, Mihaljevic T, Phillips BJ, Aranki SF, Rawn JD, Cohn LH: Biological vs. mechanical aortic root replacement. Eur J Cardiothorac Surg 2003, 23:305-310.

7. Dossche KM, Schepens MA, Morshuis WJ, de la Riviere AB, Knaepen PJ, Vermeulen FE: A 23-year experience with composite valve graft replacement of the aortic root. Ann Thorac Surg 1999, 67:1070-1077.

8. Ehrlich MP, Ergin MA, McCullough JN, Lansman SL, Galla JD, Bodian CA, Griepp RB: Favorable outcome after composite valve- graft replacement in patients older than $\mathbf{6 5}$ years. Ann Thorac Surg 2001, 7I: 1454-I459.

9. Etz CD, Homann TM, Rane N, Bodian CA, Di Luozzo G, Plestis KA, Spielvogel D, Griepp RB: Aortic root reconstruction with a bioprosthetic valved conduit: a consecutive series of $\mathbf{2 7 5}$ procedures. J Thorac Cardiovasc Surg 2007, I 33: |455-| 463.

10. Kallenbach K, Karck M, Pak D, Salcher R, Khaladj N, Leyh R, Hagl C, Haverich $A$ : Decade of aortic valve sparing reimplantation: are we pushing the limits too far? Circulation 2005, I I 2:1253-259.

II. Lewis CT, Cooley DA, Murphy MC, Talledo O, Vega D: Surgical repair of aortic root aneurysms in $\mathbf{2 8 0}$ patients. Ann Thorac Surg 1992, 53:38-45.

12. Pacini D, Ranocchi F, Angeli E, Settepani F, Pagliaro M, Martin-Suarez $\mathrm{S}$, Di Bartolomeo R, Pierangeli A: Aortic root replacement with composite valve graft. Ann Thorac Surg 2003, 76:90-98.

13. Svensson LG: Rationale and technique for replacement of the ascending aorta, arch, and distal aorta using a modified elephant trunk procedure. J Card Surg 1992, 7:30I-3I2.

14. Edmunds LH Jr, Clark RE, Cohn LH, Grunkemeier GL, Miller DC, Weisel RD: Guidelines for reporting morbidity and mortality after cardiac valvular operations. Ad Hoc Liaison Committee for Standardizing Definitions of Prosthetic Heart Valve Morbidity of The American Association for Thoracic Surgery and The Society of Thoracic Surgeons. J Thorac Cardiovasc Surg 1996, I I 2:708-7II.

15. Kumar P, Zehr KJ, Chang A, Cameron DE, Baumgartner WA: Quality of life in octogenarians after open heart surgery. Chest 1995, 108:919-926.

16. Hagl C, Khaladj N, Karck M, Kallenbach K, Leyh R, Winterhalter M, Haverich A: Hypothermic circulatory arrest during ascending and aortic arch surgery: the theoretical impact of different cerebral perfusion techniques and other methods of cerebral protection. Eur J Cardiothorac Surg 2003, 24:37I-378.

17. Galla JD, Lansman SL, Spielvogel D, Minanov OP, Ergin MA, Bodian CA, Griepp RB: Bioprosthetic valved conduit aortic root reconstruction: the Mount Sinai experience. Ann Thorac Surg 2002, 74:SI769-I772.

18. David TE, Feindel CM: An aortic valve-sparing operation for patients with aortic incompetence and aneurysm of the ascending aorta. J Thorac Cardiovasc Surg 1992, 103:617-621.

19. Kouchoukos NT, Wareing TH, Murphy SF, Perrillo JB: Sixteen-year experience with aortic root replacement. Results of 172 operations. Ann Surg 1991, 2 I 4:308-318.

20. Svensson LG, Crawford ES, Hess KR, Coselli JS, Safi HJ: Composite valve graft replacement of the proximal aorta: comparison of techniques in 348 patients. Ann Thorac Surg 1992, 54:427-437.

21. Urbanski PP, Wagner M, Zacher M, Hacker RW: Aortic root replacement versus aortic valve replacement: a case-match study. Ann Thorac Surg 2001, 72:28-32.

22. Craver JM, Puskas JD, Weintraub WW, Shen Y, Guyton RA, Gott JP, Jones EL: 601 octogenarians undergoing cardiac surgery: outcome and comparison with younger age groups. Ann Thorac Surg 1999, 67: I104-11110.

23. Hannan EL, Racz MJ, Jones RH, Gold JP, Ryan TJ, Hafner JP, Isom OW: Predictors of mortality for patients undergoing cardiac valve replacements in New York State. Ann Thorac Surg 2000, 70:1212-1218.

24. Jamieson WR, Edwards FH, Schwartz M, Bero JW, Clark RE, Grover FL: Risk stratification for cardiac valve replacement. National Cardiac Surgery Database. Database Committee of The Society of Thoracic Surgeons. Ann Thorac Surg 1999, 67:943-95 I.

25. Shrestha M, Khaladj N, Baraki H, Haverich A, Hagl C: Is there an Age Limit for Cardiac Surgery? Clinical Medicine: Geriatrics 2008, 2:3I-33.

26. Shrestha $M$, Khaladj $N$, Haverich $A$, Hagl $C$ : Is treatment of acute type $\mathbf{A}$ aortic dissection in septuagenarians justifiable? Asian Cardiovasc Thorac Ann 2008, 16:33-36.

27. Khaladj N, Shrestha M, Meck S, Peterss S, Kamiya H, Kallenbach K, Winterhalter M, Hoy L, Haverich A, Hagl C: Hypothermic circulatory arrest with selective antegrade cerebral perfusion in ascending aortic and aortic arch surgery: a risk factor analysis for adverse outcome in $50 \mathrm{I}$ patients. J Thorac Cardiovasc Surg 2008, 135:908-914.

28. Khaladj N, Shrestha M, Peterss S, Kutschka I, Strueber M, Hoy L, Haverich A, Hagl C: Isolated surgical aortic valve replacement after previous coronary artery bypass grafting with patent 
grafts: is this old-fashioned technique obsolete? Eur J Cardiothorac Surg 2009, 35:260-264.

29. Hagl C, Strauch JT, Spielvogel D, Galla JD, Lansman SL, Squitieri R, Bodian CA, Griepp RB: Is the Bentall procedure for ascending aorta or aortic valve replacement the best approach for long-term event-free survival? Ann Thorac Surg 2003, 76:698-703.

30. Scott WC, Miller DC, Haverich A, Dawkins K, Mitchell RS, Jamieson SW, Oyer PE, Stinson EB, Baldwin JC, Shumway NE: Determinants of operative mortality for patients undergoing aortic valve replacement. Discriminant analysis of 1,479 operations. J Thorac Cardiovasc Surg 1985, 89:400-4I3.

31. Nowicki ER, Birkmeyer NJ, Weintraub RW, Leavitt BJ, Sanders JH, Dacey LJ, Clough RA, Quinn RD, Charlesworth DC, Sisto DA, et al.: Multivariable prediction of in-hospital mortality associated with aortic and mitral valve surgery in Northern New England. Ann Thorac Surg 2004, 77:1966-1977.

32. Radu NC, Kirsch EW, Hillion ML, Lagneau F, Drouet L, Loisance D: Embolic and bleeding events after modified Bentall procedure in selected patients. Heart 2007, 93:107-II2.

Publish with Bio Med Central and every scientist can read your work free of charge

"BioMed Central will be the most significant development for disseminating the results of biomedical research in our lifetime. "

Sir Paul Nurse, Cancer Research UK

Your research papers will be:

- available free of charge to the entire biomedical community

- peer reviewed and published immediately upon acceptance

- cited in PubMed and archived on PubMed Central

- yours - you keep the copyright

Submit your manuscript here:

http://www.biomedcentral.com/info/publishing_adv.asp 